\title{
Effect of Different Solar Radiation Data Sources on the Variation of Techno-Economic Feasibility of PV Power System
}

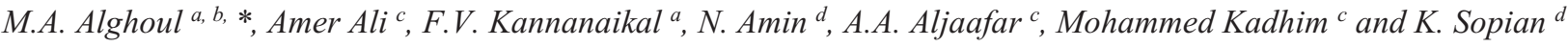 \\ ${ }^{a}$ Energy and Building Research Center, Kuwait Institute for Scientific Research, Safat 13109, Kuwait \\ ${ }^{b}$ Center of Research Excellence in Renewable Energy (CoRe-RE), Research Institute, King Fahd University of \\ Petroleum and Minerals (KFUPM), Dhahran 31261, Saudi Arabia \\ ${ }^{c}$ The School of Applied Physics, Faculty of Science and Technology, Universiti Kebangsaan Malaysia \\ ${ }^{d}$ Solar Energy Research Institute, Universiti Kebangsaan Malaysia, 43600 Bangi, Selangor, Malaysia \\ *Corresponding author e-mail:dr.alghoul@gmail.com
}

\begin{abstract}
The aim of this study is to evaluate the variation in techno-economic feasibility of PV power system under different data sources of solar radiation. HOMER simulation tool is used to predict the techno-economic feasibility parameters of PV power system in Baghdad city, Iraq located at $\left(33.3128^{\circ} \mathrm{N}, 44.3615^{\circ} \mathrm{E}\right)$ as a case study. Four data sources of solar radiation, different annual capacity shortages percentage $(0,2.5,5$, and 7.5$)$, and wide range of daily load profile (10-100 kWh/day) are implemented. The analyzed parameters of the techno-economic feasibility are COE $(\$ / \mathrm{kWh}), \mathrm{PV}$ array power capacity $(\mathrm{kW}), \mathrm{PV}$ electrical production $(\mathrm{kWh} /$ year), No. of batteries and battery lifetime (year). The main results of the study revealed the followings: (1) solar radiation from different data sources caused observed to significant variation in the values of the techno-economic feasibility parameters; therefore, careful attention must be paid to ensure the use of an accurate solar input data; (2) Average solar radiation from different data sources can be recommended as a reasonable input data; (3) it is observed that as the size and of PV power system increases, the effect of different data sources of solar radiation increases and causes significant variation in the values of the techno-economic feasibility parameters.
\end{abstract}

Keywords: PV power systems, climate databases available online, effect of solar radiation from different climate databases, variation of techno-economic feasibility parameters

\section{INTRODUCTION}

In the literature, numerous researches discussed the techno-economic feasibility of hybrid renewable power systems [1-6] or PV power systems [7-10] using HOMER simulation tool. Techno-economic feasibility studies in the literature variated in their input data resources due to many climate databases available online. However, effect of different data sources of solar radiation on the techno-economic feasibility of PV systems are still a missing link in the literature despite there are many research areas in the literature investigated the effect of different data sources on the outcome of their studies [11-14]. Moreover, previous techno-economic feasibility studies usually dealt with a case study (a specific load for a respective location). Generalizing the outcome versus wide range of daily loads instead of a specific load is most effective. Therefore, the aim of this study is to enrich the literature with new research on the effect of different data sources of solar radiation on techno-economic feasibility of the PV power system versus wide range of daily loads. To success the verification, four data sources of solar radiation, different annual capacity shortages percentages $(0,2.5,5$, and 7.5$)$ and wide range of daily load profile (10-100) $\mathrm{kWh}$ /day are implemented under Baghdad city location.

\section{Materials and methods}

Baghdad, Iraq's capital located at $33^{\circ}$ latitude and $44^{\circ}$ longitude. The monthly solar radiation from different data sources for Baghdad city is shown in Table 1. The solar radiation data sources are: Nasa climate site (SRC1) [15], weather base climate site (SRC2) [16], meteorological department data (Iraq) SRC3: (1984-2004) [17] and meteorological department data: (1962-1992) (Iraq) SRC4 [18]. The variation of monthly solar radiation obtained from different data sources is plotted in figure 1. 
The techno-economic feasibility parameters such as COE $(\$ / \mathrm{kWh}), \mathrm{PV}$ array power capacity $(\mathrm{kW})$, PV electrical production (kWh/year), No. of batteries, Battery lifetime (year) were simulated using HOMER. Then, the values of these parameters are compared to measure the significance of variation due to solar radiation from different data sources. Block diagram of the study evolution methodology is shown in Fig.2.

Table 1: Monthly solar radiation from different data sources for Baghdad city

\begin{tabular}{|c|c|c|c|c|}
\hline \multirow[b]{2}{*}{ Month } & \multicolumn{4}{|c|}{ Monthly Solar Radiation $\left(\mathrm{kWh} / \mathrm{m}^{2}\right)$} \\
\hline & $\begin{array}{l}\text { SRC1: } \\
\text { Climate site } \\
\text { (Nasa) }\end{array}$ & $\begin{array}{c}\text { SRC2: } \\
\text { Climate site } \\
\text { (Weather base) }\end{array}$ & $\begin{array}{c}\text { SRC3: } \\
\text { Meteorological } \\
\text { department data } \\
(1984-2004)\end{array}$ & $\begin{array}{c}\text { SRC4: } \\
\text { Meteorological } \\
\text { department data } \\
(1962-1992)\end{array}$ \\
\hline January & 3.08 & 2.97 & 2.96 & 3.07 \\
\hline February & 4.09 & 4.03 & 4.03 & 3.98 \\
\hline March & 5.16 & 4.97 & 4.97 & 4.97 \\
\hline April & 6.19 & 5.39 & 5.44 & 6.03 \\
\hline May & 7.15 & 6.47 & 6.48 & 6.87 \\
\hline June & 7.57 & 7.56 & 7.58 & 7.87 \\
\hline July & 7.45 & 7 & 6.99 & 7.75 \\
\hline August & 6.94 & 6.77 & 6.71 & 7.28 \\
\hline September & 6.23 & 5.56 & 5.55 & 6.16 \\
\hline October & 4.56 & 3.97 & 3.97 & 4.62 \\
\hline November & 3.37 & 2.97 & 2.86 & 3.41 \\
\hline December & 2.67 & 2.61 & 2.64 & 2.88 \\
\hline
\end{tabular}

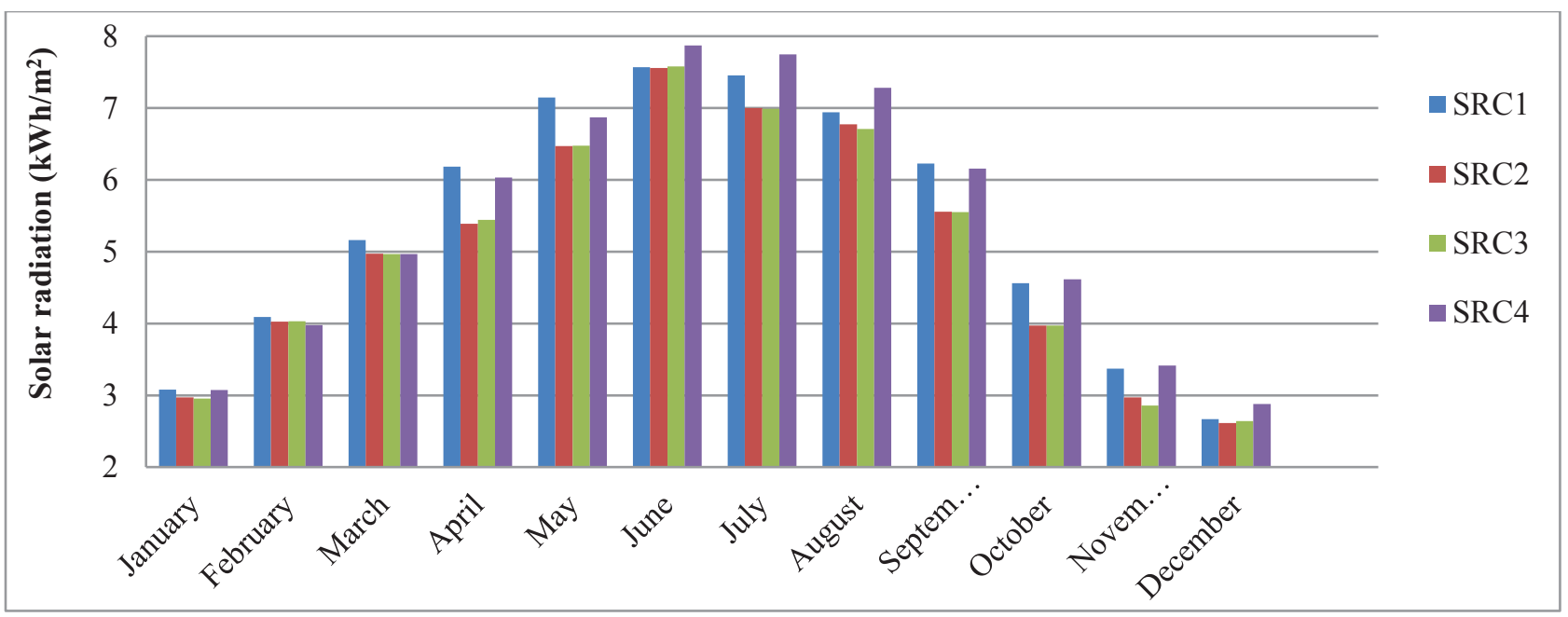

Fig 1: Variation of monthly solar radiation obtained from different data sources 


\begin{tabular}{|c|c|c|}
\hline & $\begin{array}{l}\text { Implemented solar radiation input } \\
\text { data: (4) different data sources }\end{array}$ & Location of the study: Baghdad city \\
\hline Input data/ & $\begin{array}{l}\text { Implemented daily load profile range: } \\
(10-100 \mathrm{kWh})\end{array}$ & $\begin{array}{l}\text { PV Panel (CS6X-295M): } 295 \text { W } \\
\text { Cost } 500 \text { US\$, replacement cost } 436 \text { US\$) }\end{array}$ \\
\hline $\begin{array}{l}\text { Components/ } \\
\text { Design scope }\end{array}$ & $\begin{array}{l}\text { Implemented annual capacity } \\
\text { shortage: }(0,2.5 \%, 5 \% \text {, and } 7.5 \%)\end{array}$ & $\begin{array}{l}\text { Battery type (RA12): }(260 \mathrm{Ah}, 12 \mathrm{~V}, 3.12 \mathrm{kWh}) \\
\text { Cost } 900 \text { US\$, replacement cost } 900 \mathrm{US} \$)\end{array}$ \\
\hline & & $\begin{array}{l}\text { Converter (capital/ replacement) } \\
\text { Cost: } 1095 \$ / \mathrm{kW}\end{array}$ \\
\hline & & ----------------- \\
\hline $\begin{array}{l}\text { Simulation } r \\
\text { (Techno-eco }\end{array}$ & $\begin{array}{l}\text { Its of PV power system: } \\
\text { nic feasibility parameters) }\end{array}$ & $\begin{array}{ll}\text { 1. } & \mathrm{COE}(\$ / \mathrm{kWh}) \\
\text { 2. } & \mathrm{PV} \text { array power capacity }(\mathrm{kW}) \\
\text { 3. } & \mathrm{PV} \text { electrical production }(\mathrm{kWh} / \text { year }) \\
\text { 4. } & \text { No. of batteries } \\
\text { 5. } & \text { Battery lifetime (year) }\end{array}$ \\
\hline & --------------1 & 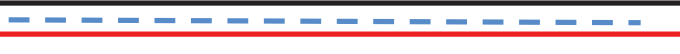 \\
\hline $\begin{array}{l}\text { Research } \\
\text { objectives }\end{array}$ & $\begin{array}{l}\text { To verify the effect of different solar } \\
\text { radiation data sources on the values of } \\
\text { techno-economic feasibility } \\
\text { parameters of PV power system versus } \\
\text { wide range of daily loads profile ( } 10 \text { - } \\
100 \mathrm{kWh} \text { ) and under annual capacity } \\
\text { shortages } 0 \% \text {. }\end{array}$ & $\begin{array}{l}\text { To extend the impact of different solar data } \\
\text { sources on the techno-economic feasibility } \\
\text { parameters under other annual capacity shortage } \\
\text { values }(2.5 \%, 5 \% \text { and } 7.5 \%) \text {. }\end{array}$ \\
\hline
\end{tabular}

Fig. 2. Block diagram of the study evolution methodology

\section{SIMULATION RESULTS AND DISCUSSION}

Figure 3 illustrates the effect of multiple data sources of solar radiation on COE of PV power system versus wide range of daily load profile $(10 \mathrm{kWh}-100 \mathrm{kWh})$ for different annual capacity shortage. It can be seen that different data sources leaded to obvious variation in COE values for each capacity shortage. Comparison between the effects of these solar resources specifies that SRC3 and SRC4 are the most diverging resources at all capacity shortages with a maximum deviation of $22 \%$. SRC1 and SRC2 vary at $0 \%$ capacity shortage but later at higher capacity shortage values they tend to converge. At the low load range, higher and unstable COE values can be witnessed meanwhile at medium and higher loads, stable COE values can be found. This is attributed to the fact that the adopted components are considered oversize for small loads. For example, the analysis showed that the adopted battery type (RA12, 260Ah, $12 \mathrm{~V}, 3.12 \mathrm{kWh}$ ) in this study is found oversize when designing PV system of small load.

Figure 4 illustrates the effect of multiple data sources of solar radiation (SRC1, SRC2, SRC3 and SRC4) on PV array power capacity versus wide range of daily load profile (10kWh-100kWh) for annual capacity shortage $(0 \%$ and $5 \%)$. It can be perceived that different data sources of solar radiation lead to higher variation of PV array power at capacity shortage $(0 \%)$ compare of that at capacity shortage $(5 \%)$.

Figure 5 plots the effect of multiple data sources of solar radiation (SRC1, SRC2, SRC3 and SRC4) on PV electrical production versus wide range of daily load profile $(10 \mathrm{kWh}-100 \mathrm{kWh})$ for annual capacity shortage $(0 \%$ and $5 \%)$. The results revealed that different data sources of solar radiation lead to significant variation of PV electrical production at annual capacity shortage $(0 \%)$ while this variation vanished at capacity shortage $(5 \%)$. 
Figure 6 displays the effect of multiple data sources of solar radiation (SRC1, SRC2, SRC3 and SRC4) on No. of batteries versus wide range of daily load profile $(10 \mathrm{kWh}-100 \mathrm{kWh})$ for annual capacity shortage $(0 \%$ and $5 \%)$. It can be seen clearly that different data sources of solar radiation lead to significant variation in No of batteries at both capacity shortages.

Finally, effect of different data sources (SRC1, SRC2, SRC3 and SRC4) of solar radiation on battery lifetime at capacity shortage $(0 \%$ and $5 \%)$ is shown in Fig $7(\mathrm{a}-\mathrm{b})$ respectively. It is seen that different data sources of solar radiation leaded to significant variation in battery lifetime at capacity shortages $5 \%$ compare of that at capacity shortage $0 \%$.

(a) Capacity shortage $(0 \%)$

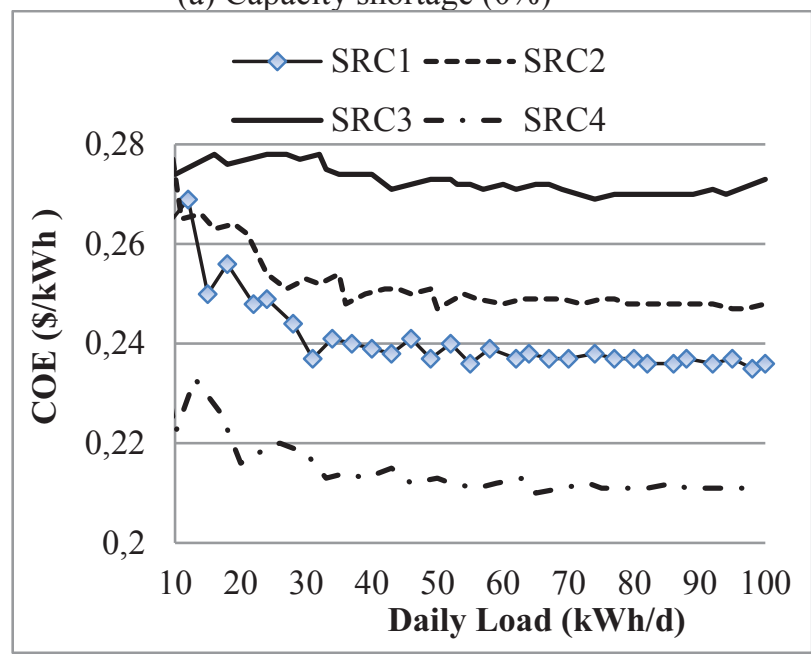

(c) Capacity shortage $(5 \%)$

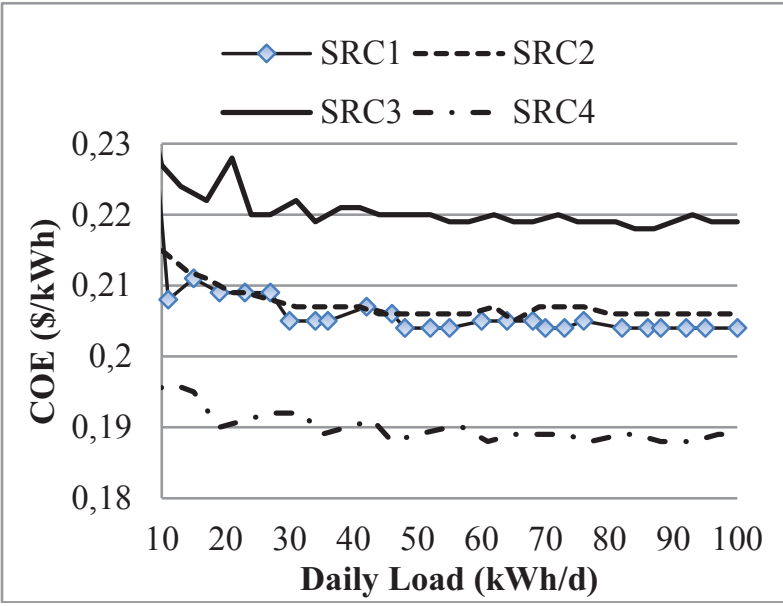

(b) Capacity shortage $(2.5 \%)$

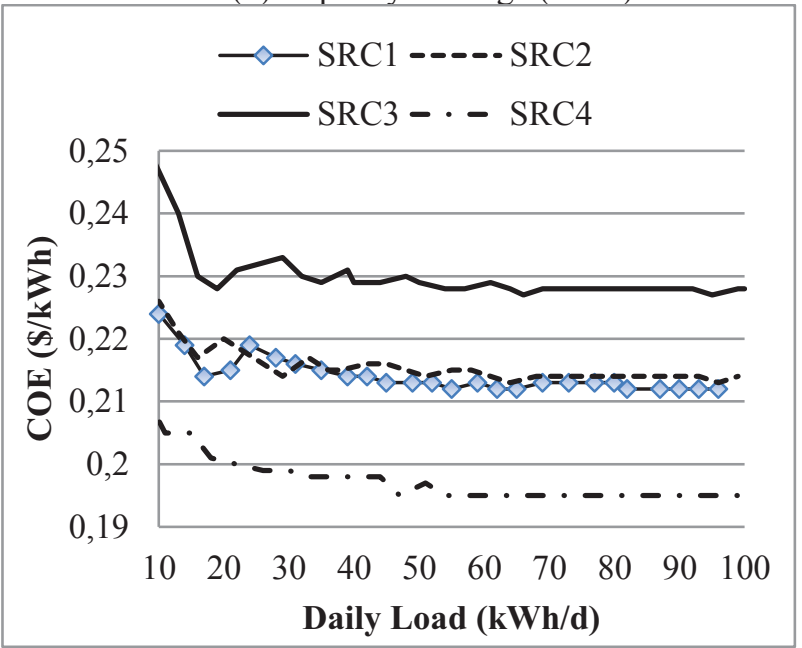

(d) Capacity shortage $(7.5 \%)$

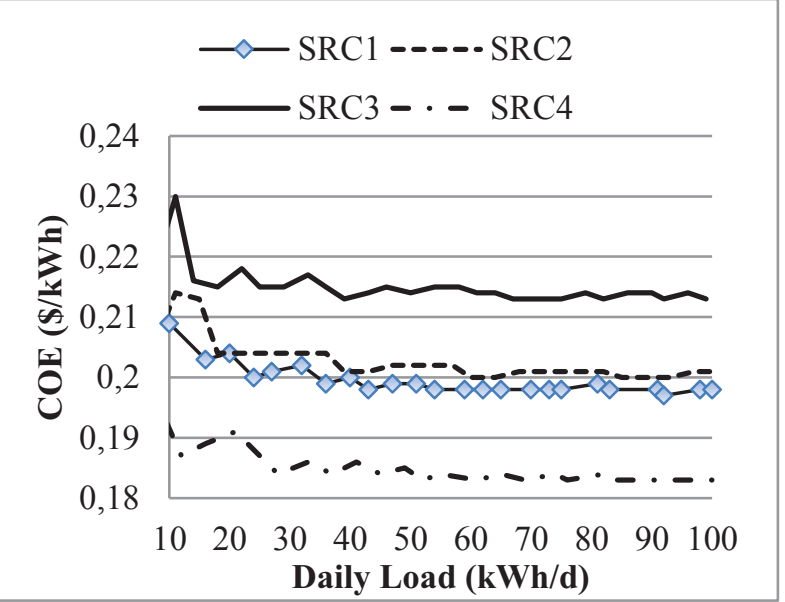

Fig 1 (a-d): COE of PV power system versus daily load profile at four data sources of solar radiation and different annual capacity shortage 
(a) Capacity shortage $(0 \%)$

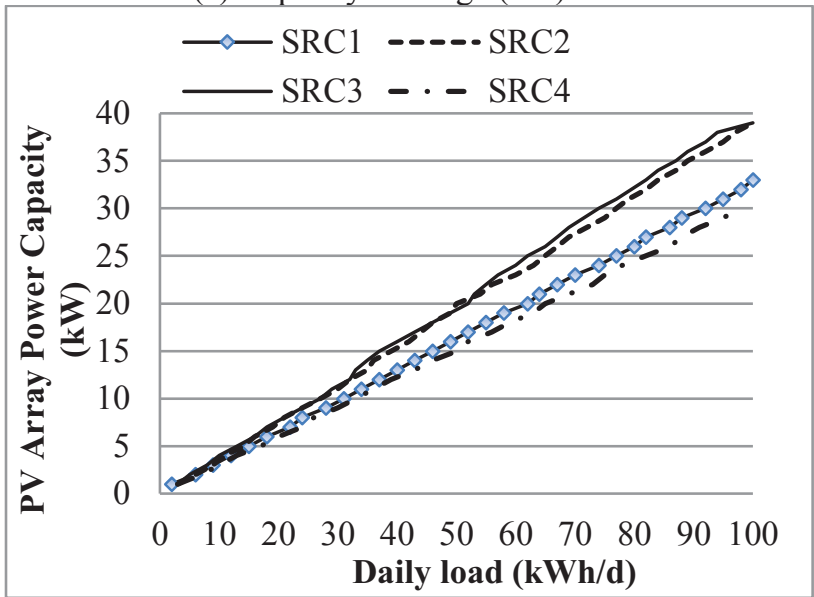

(b) Capacity shortage (5\%)

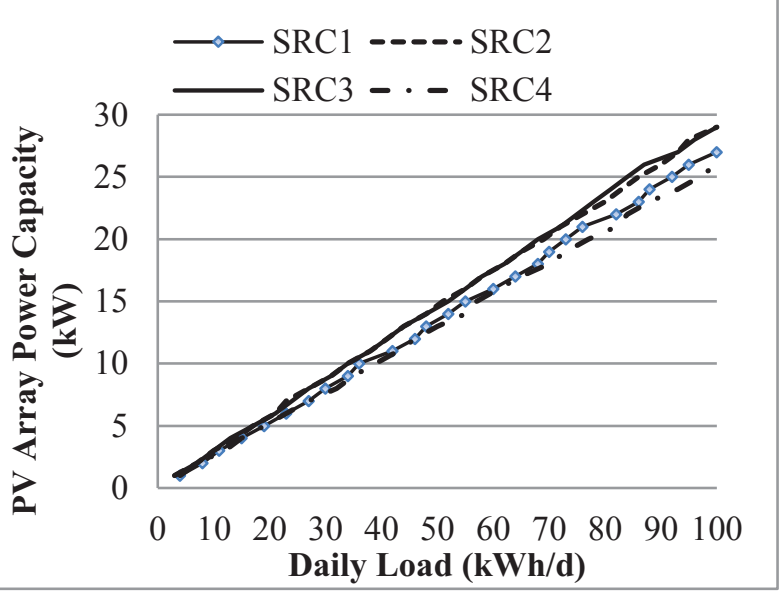

Fig 4 (a-b): PV array power capacity of PV system versus daily load profile at four data sources of solar radiation and two different annual capacity shortage

(a) Capacity shortage $(0 \%)$

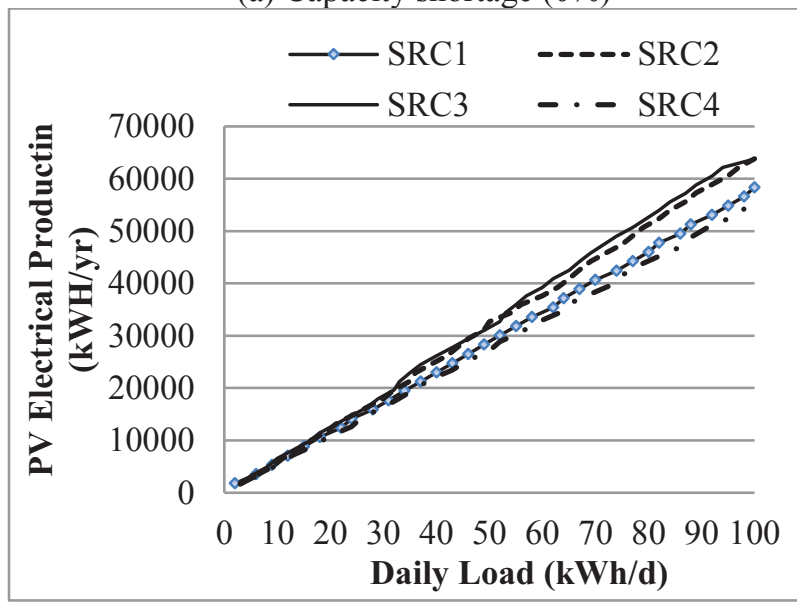

(b) Capacity shortage (5\%)

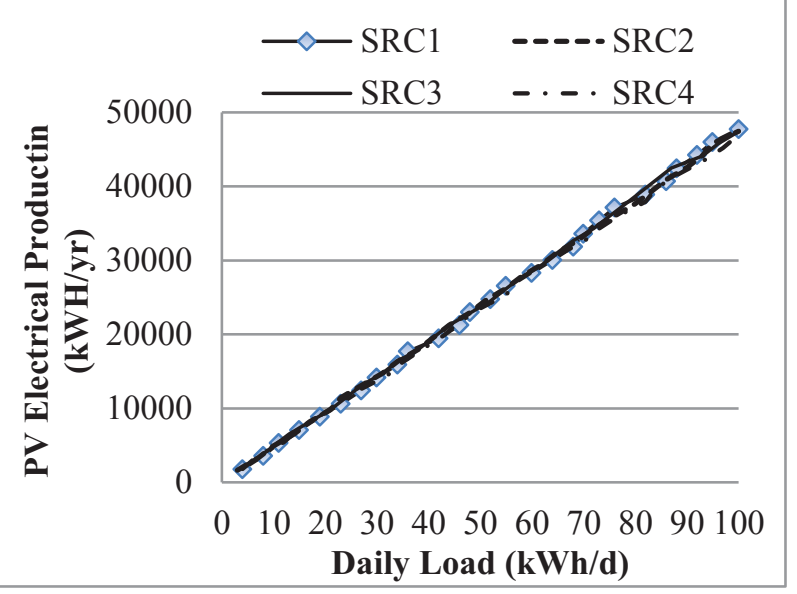

Fig 5 (a-b): PV electrical production of PV power system versus daily load profile at four data sources of solar radiation and two different annual capacity shortage
(a) Capacity shortage $(0 \%)$
(b) Capacity shortage (5\%) 

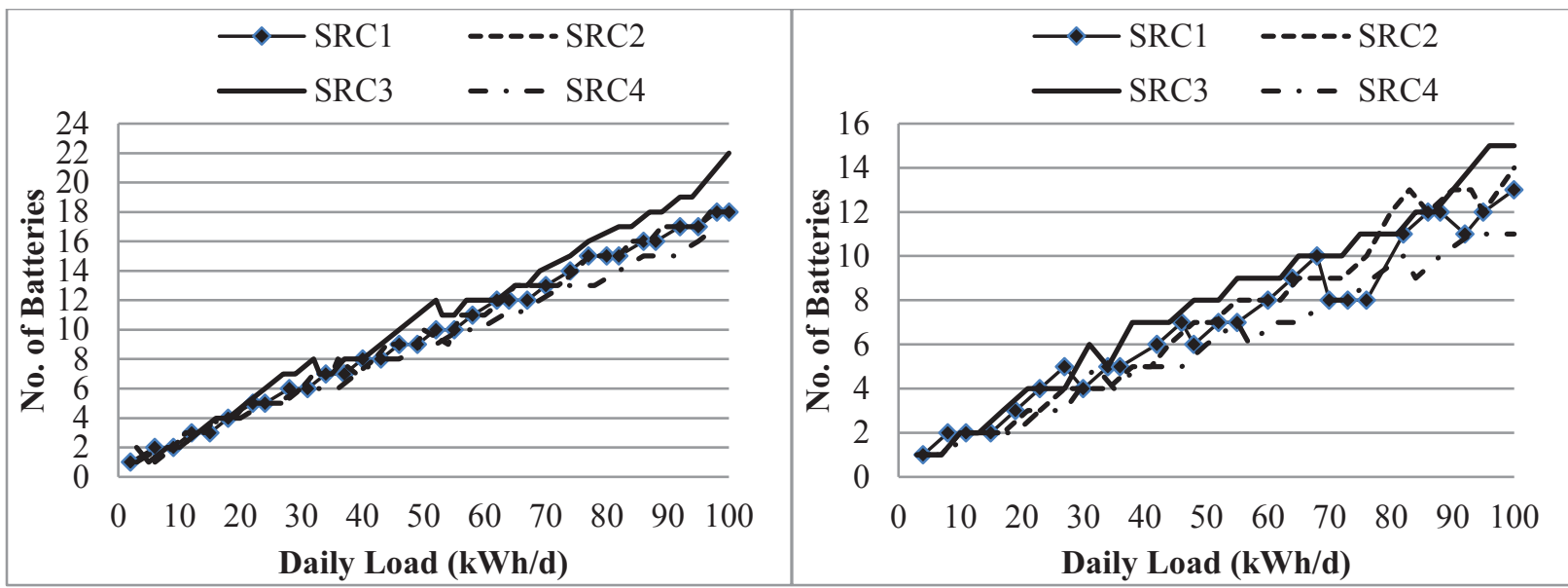

Fig 6 (a-b): No. of batteries of PV power system versus daily load profile at four data sources of solar radiation and two different capacity shortages

(a) Capacity shortage $(0 \%)$

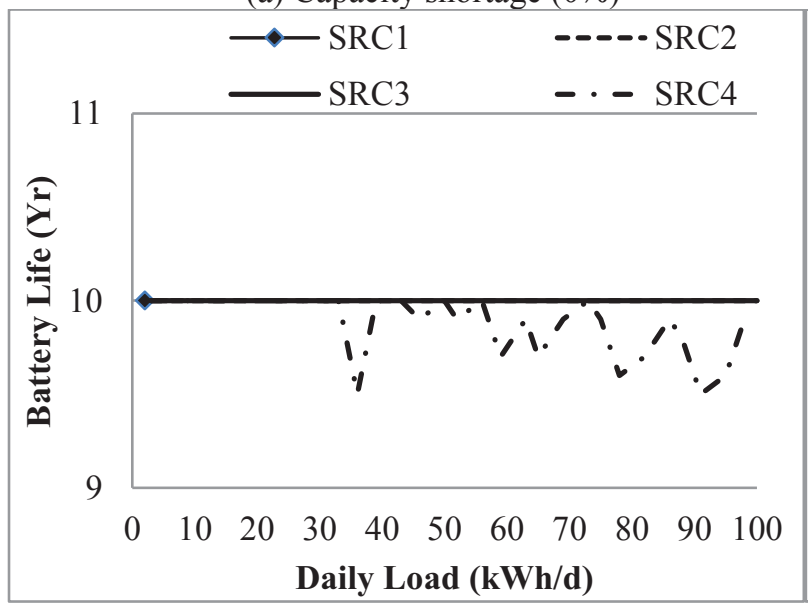

(b) Capacity shortage (5\%)

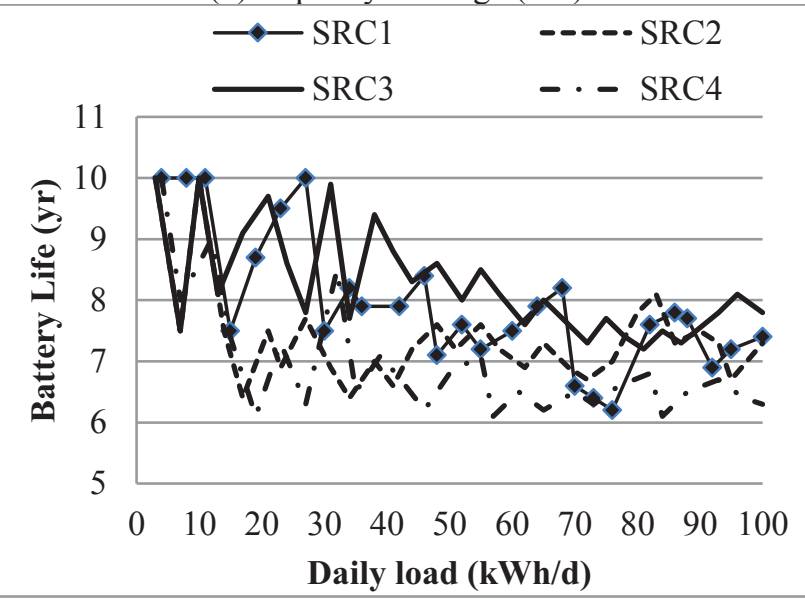

Fig. 7(a-b): Battery lifetime of PV power system versus daily load profile at four data sources of solar radiation and two different annual capacity shortage

\section{CONCLUSION}

The outcomes from this study are drawn as below:

- Solar radiation data from different data sources of Baghdad city caused variations in the values of the technoeconomic feasibility parameters. So, careful attention must be paid to implement the proper input data of solar radiation in future works.

- This outcome of this study urge the authors to recommend average solar radiation from different data sources to be used as accurate input data for achieving the optimum techno-economic feasibility of PV power systems in future works.

\section{Referencies:}

[1] Braun. M., Girma. Z. 2013. Techno Economic Assessment and Optimization Study of Hybrid Power System Using Homer Software for Electrification of Rural District in Ethiopia. International Journal of Renewable Energy Research. 3(3). 
[2] Widatalla. A. M, Zinko. H. 2011. Designing a Photovoltaic Solar Energy System for a Commercial Building. Case Study: Rosa Park Hotel in Khartoum-Sudan. World Renewable Energy Congress. Vol. 11.

[3] Sopian, K., Zaharim, A., Ali, Y., Nopiah, Z.M., Razak, J.A. and Muhammad, N.S., 2008. Optimal operational strategy for hybrid renewable energy system using genetic algorithms. WSEAS Transactions on Mathematics, 7(4), pp.130-140. ISSN: 1109-2769.

[4] Shaahid, S.M \& Elhadidy, M.A.2005. Economic analysis of hybrid photovoltaic-diesel-battery power systems for residential loads in hot regions - A step to clean future. Renewable and Sustainable Energy Reviews 11: 635653.

[5] Shaahid, S.M. \& Elhadidy, M.A. 2006. Technical and economic assessment of grid-independent hybrid photovoltaic-diesel-battery power systems for commercial loads in desert environments. Renewable and Sustainable Energy Reviews 11: 1794-1810.

[6] Malika Amini .2010. Renewable Energy Systems for Rural Health Clinics in Algeria: Homer Application. Energy 14: 1120-1130. http://homerenergy.com/webcast-downloads/Malika_Amini/health.pdf

[7] Amal A. Hassan, Abd El-Shafy A,Nafeh, Faten H. Fahmy \&Mohamed A. El- Sayed. 2010. Stand-Alone Photovoltaic System for an Emergency Health Clinic. International Conference on Renewable Energies and Power Quality. (ICREPQ'10).

[8] I. M. Saleh Ibrahim Al-Jadi Photovoltaic in Libya Applications and evaluation. Proceedings of the International Conference on Renewable Energy for Developing Countries-20 http://www.udc.edu/docs/cere/PHOTOVOLTAIC\%20IN\%20LIBYA.pdf

[9] Al-Karaghouli, A., \& Kazmerski, L. L. 2010. Optimization and life-cycle cost of health clinic PV system for a rural area in southern Iraq using HOMER Software.Solar Energy, 84(4), 710-714.

[10] Kazem, H.A., Ali, S.Q., Alwaeli, A.H., Mani, K. and Chaichan, M.T., (2013). Life-cycle cost analysis and optimization of health clinic PV system for a rural area in Oman. In Proceedings of the World Congress on Engineering, (Vol. 2, pp. 3-5). 2013, July, London, U.K.

[11] Rogers, J.D., 2009. Comparative Analysis Involving Wind Profile Data Sources. In Proceedings of the 20th AIAA Aerodynamic Decelerator Systems Technology Conference and Seminar. pp.1-13, 4 - 7 May 2009, Seattle, Washington,USA.

[12] Ben E. Lawsona, Michael D. Dayb, Michiala Bowenc, Rieks D. van Klinkend, Myron P. Zalucki 2010. The effect of data sources and quality on the predictive capacity of CLIMEX models: An assessment of Teleonemia scrupulosa and Octotoma scabripennis for the biocontrol of Lantana camara in Australia. Biological ControlVolume 52, Issue 1, January 2010, Pages 68-76

[13] Perez- Brunius et. Al 2007. Comparison of Upwelling indices off Baja California derived from three different wind data sources. CalCOFI Rep., Vol. 48, 2007, pp. 204-2014

[14] Jin, X., Hanesiak, J.M. and Barber, D.G., 2007. Time series of daily averaged cloud fractions over landfast firstyear sea ice from multiple data sources. Journal of Applied Meteorology and Climatology, 46(11), pp.18181827.

[15] https://eosweb.larc.nasa.gov/sse/RETScreen/

[16] www.weatherbase.com

[17] Tadros, M. T. Y., Mustafa, M. A. M., \& Abdel-Wahab, M. 2014. Estimation of the Global Horizontal Solar Radiation in Iraq. International Journal of Emerging Technology and Advanced Engineering Website: www.ijetae.com (ISSN 2250-2459, ISO 9001:2008 Certified Journal, Volume 4, Issue 8, August 2014)

[18] Mahdy, A. and Godu, H.A., 2010. Calculation and applications of net solar radiation in Iraq. Journal of alqadisiyah for pure science (quarterly), 15(1), pp.1-30. 